\title{
Potential drug delivery system: study of the association of a model nitroimidazole drug with aggregates of amphiphilic polymers on aqueous solution
}

\author{
Constain Hugo Salamanca Mejia ${ }^{1 *}$, Bruno Felipe Urbano², Andres Floreal Olea Carrasco ${ }^{3}$
}

${ }^{1}$ Program of Pharmacy, Faculty of Natural Sciences, University ICESI, Cali, Colombia ${ }^{2}$ Department of Chemistry, Faculty of Sciences, University of Chile, Santiago, Chile ${ }^{3}$ Department of Chemical Sciences, Faculty of Ecology and Natural Resources, University Andres Bello, Santiago, Chile

\begin{abstract}
This study evaluated the association of $N$-hexyl-2-methyl-4-nitroimidazol, a model drug, to aggregates formed by anionic polyelectrolytes on aqueous solution. The alternating copolymers of maleic anhydride and $N$-vinyl-2-pyrrolidone were synthesized and then modified by reaction of the anhydride groups with aliphatic amines and alcohols of varying length of the alkyl chain. The partition of the model drug between water and the hydrophobic microdomains provided by the copolymers was studied using the pseudo-phase model to determinate the distribution coefficient $K_{\mathrm{S}}$, and the standard free energy of transfer $\Delta \mu^{\circ}$. The results indicate that all copolymers assessed are potential pharmaceutical reservoirs of the model drug. Nevertheless, the solubility of $N$-hexyl-2-methyl-4-nitroimidazol on the polymeric solutions is independent from the length of the alkyl chain of the copolymer.
\end{abstract}

Uniterms: Nitroimidazole. $N$-vinil-2-pyrrolidone. Copolymers/evaluation. Maleic acid. $N$-hexil-2methyl-4-nitroimidazol. Drugs reservatories.

Realizou-se estudo sobre a associação da $N$-hexil-2-metil-4-nitroimidazol, fármaco modelo, aos agregados formados por polieletrólitos aniônicos em solução aquosa. Os copolímeros alternados de anidrido maléico e $N$-vinil-2-pirrolidona foram sintetizados e, em seguida, modificados pela reação dos grupos de anidrido com aminas e álcoois alifáticos de duração variável da cadeia alquílica. A partição do fármaco modelo entre a água e os microdomínios hidrofóbicos fornecido pelos copolímeros foi estudada usando o modelo de pseudo-fase, a fim de determinar a distribuição do coeficiente $\mathrm{K}_{\mathrm{S}}$ e a energia livre padrão de transferência $\Delta \mu^{\circ}$. Os resultados indicam que todos os copolímeros avaliados são potenciais reservatórios farmacêuticos do fármaco. No entanto, a solubilidade do $N$-hexil-2-metil-4-nitroimidazol sobre as soluções poliméricas é independente do comprimento da cadeia alquílica do copolímero.

Unitermos: Nitroimidazol. $N$-vinil-2-pirrolidona. Copolímeros/avaliação. Ácido maleico. $N$-hexil-2metil-4-nitroimidazol. Reservatórios farmacêuticos.

\section{INTRODUCTION}

The $N$-substituted nitroimidazoles have several types of biological activity, such as antifungal (Norman et al., 1986), antiparasitic (Saadeh et al., 2009) and antimicrobial (Paramashivappa et al., 2003). Also, the inhibition of microsomal oxidation by substituted nitroimidazoles seems to be significantly influenced by the alkyl chain

\footnotetext{
*Correspondence: C. H. Salamanca. Programa de Farmacia, Facultad de Ciencias Naturales, Universidad ICESI, Calle 18 № 122-135, Cali-Colombia. E-mail: chsalamanca@icesi.edu.co
}

length in the nitroimidazole. However, the increase of the length of the side alkyl chain leads to a remarkable decrease in the solubility in aqueous solution (Miller et al., 1983; Khabnanideh et al., 2003). One of the strategies currently used to enhance the solubility of poorly soluble drugs in aqueous media is the use of amphiphilic polymeric systems, which provide a hydrophobic environment in aqueous solutions. For many years, much effort has been dedicated to the study of solution properties of synthetic water-soluble polymers carrying oil-soluble substituents, which might be used as potential pharmaceutical matrices (Dubin, Strauss, 1970; Chu, Thomas, 1987; Olea, Thomas, 
1989; Olea et al., 1999; Petit-Agnely 2000). In aqueous solutions, the non-polar groups of these polymers collapse into a non-polar environment to minimize the hydrophobic interactions. In the regime of low polymer concentration, this self-aggregation process involves groups from only one polymer chain, resulting in a contraction of the polymer coil. The resulting hydrophobic microdomains have been called intrapolymer micelles, and this feature turns hydrophobic polyelectrolytes into potential container systems for many organic molecules (Olea et al., 2002; Salamanca et al., 2007; Barraza et al., 2004). Examples of hydrophobically modified polyelectrolytes (HMP) are the alternating copolymers of maleic acid with olefins (Chu, Thomas, 1987; Salamanca et al., 2007) and vinyl ethers (Dubin, Strauss, 1970; Zdanowicz, Strauss, 1993; Anthony, Zana, 1994; Qiu et al., 2002; Binana-Limbele, Zana, 1990); and monoesters of poly(maleic acid-costyrene) (Olea et al., 1999), which are known to perform a $\mathrm{pH}$-induced conformational transition. In addition, copolymers of maleic anhydride, after hydrolysis, have been found to have bioactivity due to their high carboxylate content (Sundell, Luttikhedde, 2008). In this study, an alternating copolymer of maleic anhydride and $N$-vinyl2-pyrrolidone was modified by reaction with aliphatic amines and alcohols of varying length of the alkyl chain. The presence of aggregates in aqueous solution of these HMP has been demonstrated using pyrene as a fluorescent probe (Olea, Thomas, 1989; Binana-Limbele, Zana, 1987; Deo et al., 2005). At the same time, the ability of these aggregates to incorporate organic molecules was assessed by determining the partition coefficient of $N$ hexyl-2-methyl-4-nitroimidazole ( $N$-hexyl-NIM) (Figure 1) between the aqueous phase and the polymer aggregates. This molecule is a model of antibacterial drugs containing the nitroimidazole ring. The equilibrium constants were obtained using the pseudo-phase model (Sepulveda, Lissi, Quina, 1986), and results are compared with those previously reported for poly(maleic acid-co-1-olefins) (Olea et al., 2002; Salamanca et al., 2007).

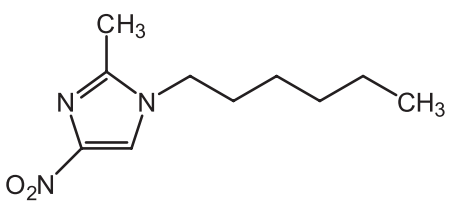

FIGURE 1 - Structure of $N$-hexyl-2-methyl-4-nitroimidazole ( $N$-hexyl-NIM).

\section{MATERIAL AND METHOD}

\section{Material}

The alternating copolymer of maleic anhydride and $N$-vinyl-2-pyrrolidone (PMAVP) was synthesized by radical polymerization, using azobisisobutyronitrile (AIBN) as initiator, and following standard procedures (Trivedi, Culbertson, 1982; Csakavari, Azori, Tudos, 1981; Georgiev, Konstantinov, Kabaivanov, 1992; Golubev, 2001). Basically, the copolymerization was carried out in benzene, under nitrogen, at $60^{\circ} \mathrm{C}$ for $72 \mathrm{~h}$. The copolymer was precipitated over hexane. The average molecular weight was obtained by viscosity measurements and use of the Mark-Houwink equation, $[\eta]=K(P M)^{\alpha}$, where $\mathrm{K}$ and $\alpha$ are $3.25 \times 10^{-4}$ and 0.67 , respectively (Csakavari, Azori, Tudos, 1981). The molecular weight was $25000 \mathrm{~g} \mathrm{~mol}^{-1}$. HMP of this copolymer were obtained by reaction of the anhydride groups with aliphatic amines and alcohol of different alkyl chain length. These reactions were carried out in DMSO at $100^{\circ} \mathrm{C}$, in the presence of 3\% 4-dimethylaminopyridine (4-DAMP) as catalyst (Figure 2). The modified copolymers are PMAVPN-n and PMAVP-O-n for the amide and ester alkyl chain; $\mathrm{n}$ is the number of carbon atoms in the alkyl side chain and its value lies in the interval $2 \leq \mathrm{n} \leq 10$.

The sodium salts of modified copolymers were obtained by dissolution of PMAVP-N-n and PMAVP-O-n in an aqueous solution of sodium bicarbonate (Figure 2). The homogeneous solution was then dialyzed against pure water until a constant conductivity value was reached. Finally, the copolymer solution was lyophilized. The

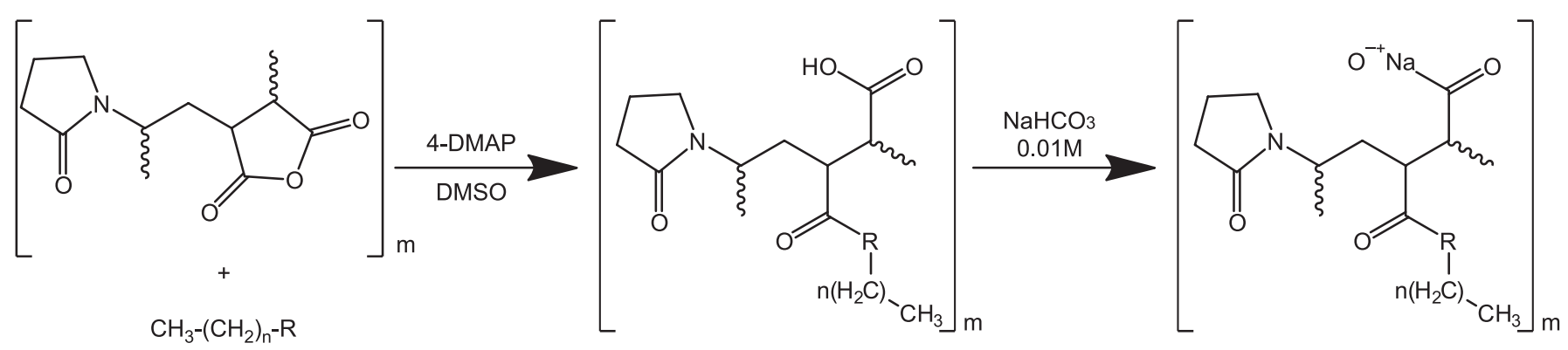

FIGURE 2 - Reaction of the anhydride group with an aliphatic amine or alcohol $\left(\mathrm{CH}_{3}-\left(\mathrm{CH}_{2}\right)_{n}-\mathrm{R}\right)$ leading to the formation of hemiamide or ester groups in poly(maleic anhydride-co-vinyl-2-pyrrolidone). 
fraction of repetitive units carrying an amide and ester side chain was determined by redissolution of the ionic copolymer and measurement of the sodium concentration using flame emission spectroscopy. The conversion of the amide and ester formation reaction, defined as the ratio of the number of amide and alcohol groups formed over the number of repetitive units, is shown in Table I. According to Figure 1, the maximum conversion (100\%) corresponds to a copolymer where each maleic anhydride has been reacted to give one carboxylic acid and one amide and ester group. All aqueous solutions of PMAVP-N-n and PMAVP-O-n were prepared using deionized water. $\mathrm{N}$-hexyl-2-methyl-4-nitroimidazole was synthesized as described previously (Salamanca et al., 2007; Salamanca, Tiznado, Jaramillo, 2010).

\section{Measurements}

Steady-state fluorescence spectra of pyrene $\left(1.3 \times 10^{-6} \mathrm{M}\right)$ in aqueous solution of $\operatorname{PMAVP}(0.5 \mathrm{mg} / \mathrm{mL})$ were recorded using a SLM Aminco SPF-500C spectrofluorometer. The excitation wavelength was set at $337 \mathrm{~nm}$, and the intensities of the third and first peaks in the pyrene emission spectrum, which appears at $382 \mathrm{~nm}$ and 373 $\mathrm{nm}$, were measured. The ratio $\mathrm{I}_{3} / \mathrm{I}_{1}$, strongly dependent on the medium polarity, has been adopted to establish an empirical micropolarity scale widely used in the study of microheterogeneous systems (Kalyanasundaram, Thomas, 1977; Dong, Winnik, 1982; Kalyanasundaram, 1987).

\section{Measurement of distribution coefficients}

Partition coefficients of hexyl-NIM, between the aqueous phase and the hydrophobic aggregates provided by the copolymers, were determined by ultrafiltration in an Amicon 202 cell with a PM5 membrane. Aqueous solutions of PMAVP-N-n and PMAVP-O-n with different concentrations of the model drug were filtered, and the absorbance of filtrates was measured at $315 \mathrm{~nm}$. The molar concentrations of hexyl-NIM in the aqueous phase $[\mathrm{NIM}]_{\mathrm{W}}$ were obtained from a calibration curve and plotted against the molar concentration of hexyl-NIM in the polymer phase $[\mathrm{NIM}]_{\mathrm{M}}$ according to equation 1 .

\section{RESULTS AND DISCUSSION}

\section{Reaction of PMAVP with alkyl amines or alcohols}

To convert PMAVP into a hydrophobically modified polyelectrolyte, the anhydride groups were reacted with aliphatic amines or alcohols to give half amides or half esters. The conversion obtained with the esterification reaction was lower than $50 \%$, whereas the reaction with amines reached conversion degrees of $81 \%-91 \%$ (see Table I) and varied only slightly with the length of the alkyl chain. These results show that, for PMAVP, the reaction of the anhydride to give the amide is more efficient than the ester formation. This result is substantially different from what has been reported for styrene-maleic anhydride copolymers, for which the conversion is 70\%-93\% for linear alcohols (Olea, Acevedo, Martinez, 1999; Hu, Lindt, 1993; Martinez et. al., 2001). The HMP obtained from the reaction of PMAVP and aliphatic amines have the advantage of varying the length of the alkyl side chain with no more than a $10 \%$ change in the number of polar groups. This feature is considerably important in studies of the properties of HMP as a function of polymer structure.

TABLE 1 - Conversion degrees for reaction of anhydride group with aliphatic amines or alcohols to give PMAVP-N-n or PMAVP-O-n

\begin{tabular}{lc}
\hline HMP & Conversion degree (\%) \\
\hline PMAVP-N-2 & 84 \\
PMAVP-N-4 & 81 \\
PMAVP-N-6 & 88 \\
PMAVP-N-8 & 87 \\
PMAVP-N-10 & 91 \\
PMAVP-O-2 & 75 \\
PMAVP-O-4 & 37 \\
PMAVP-O-6 & 34 \\
PMAVP-O-8 & 48 \\
PMAVP-O-10 & 41 \\
\hline
\end{tabular}

\section{Formation of hydrophobic microdomains by PMAVP}

Copolymers of maleic acid with alkyl vinyl ethers; 1-olefins; or styrene can form intrapolymer micelles through a conformation transition induced by $\mathrm{pH}$ (Dubbin, Strauss, 1970; Olea et al., 2002; Salamanca et al., 2007; Barraza et al., 2004). At low values of $\mathrm{pH}$, these copolymers adopt a compact form stabilized by hydrophobic interactions of the alkyl side chains. As $\mathrm{pH}$ increases, the number of carboxylate groups increases, and, therefore, the electrostatic repulsion in the polymer chain increases. As a consequence, the polymer chain stretches out adopting a random coil conformation. This transition has been monitored by measuring the intensity, lifetime, or ratio of intensities of vibronic bands of the pyrene fluorescence 
$\mathrm{I}_{3} / \mathrm{I}_{1}$ as a function of $\mathrm{pH}$ (Olea, Thomas, 1989; Chu, Thomas, 1991). Figure 3 shows that, for all MAVP-N-n copolymers, the ratio $\mathrm{I}_{3} / \mathrm{I}_{1}$ remains almost constant in the whole range of $\mathrm{pH}$. The value of $\mathrm{I}_{3} / \mathrm{I}_{1}$ ranges from 1.10 to 0.70 for copolymers with the long and short alkyl chains. These values are higher than that measured in water $(0.50)$, which indicates that pyrene is located in a hydrophobic environment provided by the polyelectrolyte. In addition, the polarity of these micelles decreases with increasing size of the alkyl side chain.

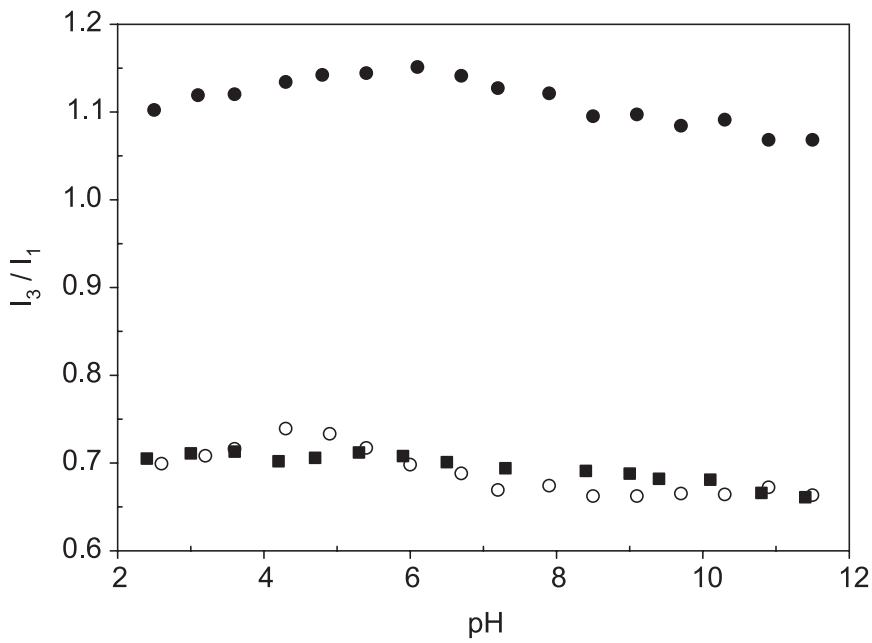

FIGURE 3 - Plot of ratio $\mathrm{I}_{3} / \mathrm{I}_{1}$ of pyrene as a function of $\mathrm{pH}$ of aqueous solutions of PMAVP-N-n copolymers. (ם) PMAVP-N-2; (○) PMAVP-N-4; (O) PMAVP-N-10.

\section{Distribution of $\mathbf{N}$-hexyl-NIM in aqueous solutions of PMAVP}

The distribution of $N$-hexyl-2-methyl-4-nitroimidazole between the aqueous phase and the microdomains provided by the PMAVP-N-n and PMAVP-O-n polymers chains was analyzed using the pseudo-phase model (Sepulveda, Lissi, Quina, 1986). According to this model, the distribution constant can be expressed on a molar concentration basis as:

$$
K_{S}=\frac{[N I M]_{M}}{[N I M]_{W}[P]_{M}} \frac{f_{M}}{f_{W}}
$$

where $[\mathrm{NIM}]_{\mathrm{M}}$ and $[\mathrm{NIM}]_{\mathrm{W}}$ are molar concentrations of $N$-hexyl-NIM in micellar and aqueous phases, $[\mathrm{P}]_{\mathrm{M}}$ is the concentration of repetitive units of PMAVP-N-n or PMAVP-O-n forming part of the micellar pseudo-phase, and $f_{M}$ and $f_{W}$ are the activity coefficients of the $N$-hexyl-NIM in the respective phase. From this experimental equilibrium constant, the thermodynamic distribution coefficient, expressed in a mole fraction basis, $\mathrm{K}_{\mathrm{X}}$, can be calculated using the equation $\mathrm{K}_{\mathrm{X}}=55.5 \mathrm{~K}_{\mathrm{s}}$. Assuming ideal behavior of the $N$-hexyl-NIM into the polymer micelles and in the aqueous phase, the molar standard free energy of transfer from aqueous solution to polymer micelles is obtained using the following equation:

$$
\Delta \mu_{\mathrm{T}}^{0}=\Delta \mu_{\mathrm{M}}^{0}-\Delta \mu_{\mathrm{W}}^{0}=\mathrm{RT} \ln \mathrm{K}_{\mathrm{X}} .
$$

The values of the distribution constants, $\mathrm{K}_{\mathrm{S}}$ and $\mathrm{K}_{\mathrm{X}}$, and the free energy of transfer $\Delta \mu_{T}^{\circ}$ in aqueous solutions of PMAVP-N-n and PMAVP-O-n at pH 7.0 are summarized in Table 2.

TABLE 2 - Distribution constants $\mathrm{K}_{\mathrm{S}}$ and $\mathrm{K}_{\mathrm{X}}$ and standard free energy of transfer $\Delta \mu_{\mathrm{T}}^{0}$ of $N$-hexyl-NIM in aqueous solution of PMAVP systems

\begin{tabular}{lccc}
\hline $\begin{array}{l}\text { Polymeric } \\
\text { System }\end{array}$ & $\boldsymbol{K} \mathbf{s}$ & $\boldsymbol{K}_{\boldsymbol{x}} \mathbf{x} \mathbf{1 0}^{-3}$ & $\begin{array}{c}-\Delta \boldsymbol{\mu}_{\mathrm{T}}^{\mathrm{o}}, \\
\mathbf{k J} \mathbf{~ m o l}^{-1}\end{array}$ \\
\hline PMAVP-N-2 & 351.76 & 19.52 & $24.46 \pm 1.22$ \\
PMAVP-N-4 & 1567.63 & 87.14 & $28.16 \pm 0.56$ \\
PMAVP-N-6 & 2175.95 & 120.76 & $28.98 \pm 0.58$ \\
PMAVP-N-8 & 341.57 & 18.96 & $24.36 \pm 0.73$ \\
PMAVP-N-10 & 182.38 & 10.12 & $22.84 \pm 0.46$ \\
PMAVP-O-2 & 892.17 & 49.52 & $26.77 \pm 1.34$ \\
PMAVP-O-4 & 194.04 & 10.77 & $22.99 \pm 1.15$ \\
PMAVP-O-6 & 1037.78 & 57.60 & $27.14 \pm 1.63$ \\
PMAVP-O-8 & 60.69 & 3.37 & $20.11 \pm 0.80$ \\
PMAVP-O-10 & 151.66 & 8.42 & $22.38 \pm 1.12$ \\
\hline
\end{tabular}

Data reveal that the distribution constants $\mathrm{K}_{\mathrm{S}}$ and $\mathrm{K}_{\mathrm{X}}$ of $N$-hexyl-NIM are higher for PMAVP-N-n copolymers than for PMAVP-O-n copolymers. This result may be assigned to the different conversion degrees obtained for each polymeric system (see Table 1). Furthermore, in both polymeric systems, the highest values of $\mathrm{K}_{\mathrm{S}}$ are obtained in those copolymers that have a side chain with six methylene groups. This result is considerably similar to that observed in the distribution of $N$-hexyl-NIM between the aqueous phase and the microdomains provided by potassium salts of poly(maleic acid-co-olefins) (Salamanca et al., 2007). At the same time, the equilibrium constant Ks decreases abruptly with further increase of the alkyl chain length in the PHM. This result may be assigned to a change of the macromolecule conformation due to enhanced interactions between alkyl chains into the hydrophobic microdomain. Consequently, the hydrophobic environment becomes more compact, hindering the inclusion of $N$-hexyl-NIM 
in the intrapolymer micelle. Thus, this substrate is less easily transferred into the aggregate, and the distribution constant decreases significantly. It should be noted that poly(vinylpyrrolidone) (PVP) has the ability to hold a variety of organic substrates through a process similar to Langmuir adsorption, in which each adsorption site involves about ten monomer units (Molyneus, Frank, 1961; Molyneus, Frank, 1961). The adsorption constants of polycyclic aromatic hydrocarbons (PAH) are in the range of $1-80 \mathrm{x}$ $10^{-7}$ (expressed in moles of substrate per gram of PVP in one liter of solution) (Lissi, Abuin, 1981). In our study, the retention constant of hexyl-NIM on polymer solutions of PMAVP at $25^{\circ} \mathrm{C}$ and $\mathrm{pH} 7.0$ ranged from of 2.5 to $25 \times 10^{-7}$ moles of substrate per gram of copolymer in one liter of solution. These results are not very different from those observed in the adsorption of PAHs in PVP solutions. Thus, it is conceivable that the retention mechanism of the substrate hexyl-NIM by PMAVP copolymers may be very similar to the one that occurs in PVP. Finally, these results demonstrate that PMAVP copolymers are potential pharmaceutical reservoir systems. However, the retention process of nitroimidazole compounds in these polymer systems in aqueous solution should be better described. For example, it is necessary to evaluate the distribution of a homologous series $N$-alkyl-NIM in aqueous solution of those polyelectrolytes that exhibit the highest $\mathrm{K}_{\mathrm{S}}$ values in the partitioning of $N$-hexyl-NIM. In addition, the effect of $\mathrm{pH}$ on the partitioning constants should be evaluated. The study of both factors is currently in progress.

\section{CONCLUSIONS}

The results obtained in this study clearly show that the anhydride groups of the alternating vinylpyrrolidonemaleic anhydride copolymer reacts efficiently with aliphatic amines to give a hemiamide. The conversion does not change with the length of the alkyl chain. Therefore, this reaction provides a way to obtain hydrophobically modified polyelectrolytes by adding an alkyl side chain with no change in the number of carboxylic groups. Moreover, the PMAVP-R-n copolymers provide a hydrophobic environment in aqueous solution, in which the drug model shows a spontaneous tendency to remain associated with the polymeric aggregates. Thus, these intrapolymer micelles may be used as potential reservoirs of pharmacological agents, such as nitroimidazoles.

\section{ACKNOWLEDGMENTS}

This study was supported by FONDECYT 1030526 and Universidad Andrés Bello DI 14-04.

\section{REFERENCES}

ANTHONY, O.; ZANA, R. Fluorescence investigation of the binding of pyrene to hydrophobic microdomains in aqueous solutions of polysoaps. Macromolecules, v.27, p.3885-3891, 1994.

BARRAZA, R.G.; OLEA, A.F.; VALDEBENITO, C.E.; DOUGNAC, V.; FUENTES, I. Solubilization of $p$-nitrophenol in aggregates formed by hydrophobically modified polyelectrolytes. J. Coll. Interf. Sci., v.275, p.434438, 2004.

BINANA-LIMBELE, W.; ZANA, R. Fluorescence probing of microdomains. 1. Use of pyrene to study the conformational state of polysoaps and their comicellization with cationic surfactants. Macromolecules, v.20, p.1331-1335, 1987.

BINANA-LIMBELE, W.; ZANA, R. Fluorescence probing of microdomains. 2. Study of the size of the microdomains. Macromolecules, v.23, p.2731-2739, 1990.

CHU, D.Y.; THOMAS, J.K. Photophysical and photochemical studies on a polymeric intramolecular micellar system, PA$18 \mathrm{~K}_{2}$. Macromolecules, v.20, p.2133-2138, 1987.

CHU, D.Y.; THOMAS, J.K. Characterization of polymers by excited state techniques, photochemistry and photophysics. Boca Raton: CRC Press, 1991. p.49-102.

CSAKAVARI, E.; AZORI, M.; TUDOS, F. Physicochemical studies of polymeric carriers 1 . Molecular mass determination of poly(N-vinylpyrrolidone-co-maleic acid) fractions. Polym. Bull, v.5, p.413-416, 1981.

DEO, P.; DEO, N.; SOMASUNDARAN, P.; JOCKUSCH, S.; TURRO, N.J. Conformational changes of pyrenelabeled polyelectrolytes with $\mathrm{pH}$ : Effect of hydrophobic modifications. J. Phys. Chem. B., v.109, p.20714-20718, 2005 .

DONG, D.C.; WINNIK, M.A. The Py scale of solvent polarities. Solvent effects on the vibronic fine structure of pyrene fluorescence and empirical correlations with ET and Y values. Photochem. Photobiol., v.35, p.17-21, 1982.

DUBIN, P.L.; STRAUSS, U.P. Hydrophobic bonding in alternating copolymers of maleic acid and alkyl vinyl ethers, J. Phys. Chem., v.74, p.2842-2847, 1970. 
GEORGIEV, G.; KONSTANTINOV, C.; KABAIVANOV, $\mathrm{V}$. Role of the charge-transfer complex during the copolymerization of $\mathrm{N}$-vinylpyrrolidone and maleicanhydride. Macromolecules, v.25, p.6302-6308, 1992.

GOLUBEV, V.B. Mechanism and kinetics of elementary reactions in alternating copolymerization of $N$-vinylpyrrolidinone with maleic anhydride. Polymer Sci., v.A 43, p.1218-1222, 2001.

HODGE, P.; TOWNS, C.R.; THOMAS, J.K.; SHACKLETON, C. Neutron reflectivity studies of spread monolayers of derivatives of styrene-maleic anhydride copolymers at the air-water interface. Langmuir, v.8, p.585-593, 1992.

HU, G.H.; LINDT, J.T. Monoesterification of styrene-maleic anhydride copolymers with alcohols in ethyl benzene: Catalysis and kinetics. J. Polym. Sci. Part A: Polym. Chem., v.31, p.691-700, 1993.

KALYANASUNDARAM, K.; THOMAS, J.K. Environmental effects on vibronic band intensities in pyrene monomer fluorescence and their application in studies of micellar systems. J. Am. Chem. Soc., v.99, p.2039-2044, 1977.

KALYANASUNDARAM, K. Photochemistry in microheterogeneous systems. Orlando: Academic Press, 1987. 12 p.

KHABNADIDEH, S.; REZAEI, Z.; KHALAFI-NEZHAD, A.; BAHRINAJAFI, R.; MOHAMADI, R.; FARROKHROZ, A.A. Synthesis of $N$-alkylated derivatives of imidazole as antibacterial agents. Bioorg. Med. Chem. Lett., v.13, p.2863-2865, 2003.

LISSI, E.A.; ABUIN, E.B. Solubilization of polyciclic aromatic hydrocarbons in water and organic phases and pseudophases. Bol. Soc. Chil. Quim., v.26, p.19-34, 1981.

MARTINEZ, F.; NECULQUEO, G.; TORRES, M.; OLEA, A.F. Monoesterification of styrene-maleic anhydride copolymers with aliphatic alcohols. Bol. Soc. Chil. Quim., v.46, p.137141, 2001.

MILLER, D.K.; GRIFFITHS, E.; LENARD, J.; FIRESTONE, R.A. Cell killing by lysosomotropic detergents. J. Cell. Biol., v.97, p.1841-1851, 1983.
MOLYNEUX, P.; FRANK, H.P. The interaction of polyvinylpyrrolidone with aromatic compounds in aqueous solution. Part I. Thermodynamics of the binding equilibria and interaction forces. J. Am. Chem. Soc., v.83, p.3169$3174,1961$.

MOLYNEUX, P.; FRANK, H.P. The interaction of polyvinylpyrrolidone with aromatic compounds in aqueous solution. Part II. The effect of the interaction on the molecular size of the polymer. J. Am. Chem. Soc., v.83, p.3175-3180, 1961 .

NORMAN, S.M.; BENNETT, R.D.; POLING, S.M.; MAIER, V.P.; NELSON, M.D. Paclobutrazol inhibits abscisic-acid biosynthesis in cercospora-rosicola. Plant Physiol., v.80, p.122-125, 1986.

OLEA, A.F.; THOMAS, J.K. Fluorescence studies of the conformational changes of poly(methacrylic acid) with $\mathrm{pH}$. Macromolecules, v.22, p.1165-1169, 1989.

OLEA, A.F.; ROSENBLUTH, H.; THOMAS, J. K. Effect of the molecular weight on the dynamics of the conformational transition of poly(methacrylic acid). Macromolecules, v.32, p.8077-8083, 1999.

OLEA, A.F.; ACEVEDO, B.; MARTINEZ, F. Effect of hydrophobic bonding on the conformational transition and properties of intramolecular micelles formed by copolymers of maleic acid and styrene. J. Phys. Chem. B., v.103, p.9306$9313,1999$.

OLEA, A.F.; BARRAZA, R.G.; FUENTES, I.; ACEVEDO, B.; MARTINEZ, F. Solubilization of phenols by intramolecular micelles formed by copolymers of maleic acid and olefins. Macromolecules, v.35, p.1049-1053, 2002.

PARAMASHIVAPPA, R.; KUMAR, P.P.; RAO, P.V.S.; RAO, A.S. Design, synthesis and biological evaluation of benzimidazole/benzothiazole and benzoxazole derivatives as cyclooxygenase inhibitors. Bioorg. Med. Chem. Lett., v.13, p.657-660, 2003.

PETIT-AGNELY, F.; ILIOPOULOS, I.; ZANA, R. Hydrophobically modified sodium polyacrylates in aqueous solutions: Association mechanism and characterization of the aggregates by fluorescence probing. Langmuir, v.16, p.9921-9927, 2000. 
QIU, Q.; LOU, A.; SOMASUNDARAN, P.; PETHICA, B.A. Intramolecular association of poly(maleic acid/octyl vinyl ether) in aqueous solution. Langmuir, v.18, p.5921-5926, 2002.

SAADEH, H.A.; MOSLEH, I.M.; EL-ABADELAH, M.M. New Synthesis and Antiparasitic activity of model 5-aryl1-methyl-4-nitroimidazoles. Molecules, v.14, p.2758-2767, 2009.

SALAMANCA, C.H.; BARRAZA, R.G.; ACEVEDO, B.; OLEA, A.F. Hydrophobically modified polyelectrolytes as potential drugs reservoirs of $N$-alkyl-nitroimidazoles. $J$. Chil. Chem. Soc., v.52, p.1025-1029, 2007.

SALAMANCA, C.; TIZNADO, W.; JARAMILLO P. Experimental and theoretical study of synthesis of N-alkylnitroimidazoles. Vitae, v.17, p.199-208, 2010.
SEPULVEDA, L.; LISSI, E.A.; QUINA, F. Interactions of neutral molecules with ionic micelles. Adv. Colloid Interf. Sci., v.25, p.1-27, 1986.

SUNDELL, A.M.; LUTTIKHEDDE, H.J.G. Drug release from ionomer cements based on hydrolyzed poly(vinylacetatemaleic anhydride). Pure Appl. Chem., v.A36, p.1045-1059, 2008.

TRIVEDI, B.C.; CULBERTSON, B.M. Maleic anhydride. New York: Plenum Press. 1982. p.335-336, 399-401

ZDANOWICZ, V.S.; STRAUSS, U.P. Intramolecular micelle size of polysoaps by luminescence quenching - role of solubilization. Macromol., v.26, p.4770-4773, 1993.

Received for publication on $22^{\text {nd }}$ February 2011 Accepted for publication on $11^{\text {th }}$ June 2011 
